\title{
Why were we wrong for so long? The pancreas of type 1 diabetic patients commonly functions for decades
}

\author{
Denise L. Faustman
}

Received: 10 September 2013 / Accepted: 16 October 2013 / Published online: 5 November 2013

(C) Springer-Verlag Berlin Heidelberg 2013

\begin{abstract}
The type 1 diabetes field has held firm to the dogma that the pancreas is no longer viable, and thus incapable of producing insulin, within 1 to 2 years of diagnosis for the majority of patients. A new study in this issue of Diabetologia (DOI: 10.1007/s00125-013-3067-x), based on a hypersensitive assay, has found detectable C-peptide, a marker of insulin production, in individuals with long-standing type 1 diabetes. This new study confirms and expands a decades-long track record of research finding intact pancreatic islet cells in advanced disease. Because the evidence, stemming back to 1902, was largely histological in nature, it was dismissed as lacking functional corroboration. This new study in patients with long-term diabetes shows appropriate functioning of pancreatic islet cells after exposure to a mixed-meal stimulus. The weight of evidence now makes it clear that a large fraction of patients with long-standing diabetes have low level, but persistent functioning of pancreatic islet cells enduring more than a decade after disease onset.
\end{abstract}

Keywords Autoimmunity · Bacillus Calmette-Guérin .

C-peptide $\cdot$ Insulin $\cdot$ Islets of Langerhans $\cdot$ Long-term

diabetes $\cdot$ Regeneration $\cdot$ Type 1 diabetes

\section{Abbreviation \\ BCG Bacillus Calmette-Guérin}

\section{Why were we wrong for so long?}

The prevailing belief of the type 1 diabetes field has been that the pancreas is essentially dead-incapable of producing

\section{L. Faustman $(\bowtie)$}

Immunobiology Laboratory, Massachusetts General Hospital,

Harvard Medical School, Building 149, 13th Street, Room 3602,

Boston, MA 02129, USA

e-mail: Faustman@helix.mgh.harvard.edu insulin - within 1-2 years of diagnosis. Those who have questioned this dogma have risked professional marginalisation. That was what happened in 1986 when I attended an international scientific meeting at which Alan Foulis presented his histological finding that patients with long-term diabetes, despite decades of illness, have rare, intact islet beta cells. Most in the audience dismissed his findings, exiting the lecture hall to make a beeline for the coffee and cookies. I sat alone in my row, just out of graduate school, experiencing one of my first exposures to scientific debate. There I heard at the microphone a critique of Foulis's finding by an outspoken scientific critic. Addressing Foulis, the scientist remarked something to the nature of, 'Your beautifully described architectural artefact of an islet in the pancreas means nothing since it has no function. You are looking at histological artefacts that are of interest to historians, not scientists or patients.'

Foulis was not even the first to histologically detect intact beta islet cells in type 1 diabetes, yet his research improved the quality of a repeated observation in post-mortem collections. The first to detect islets was the pathologist M. B. Schmidt, who in 1902 observed the rare presence of islet-like structures in an autopsy sample, albeit from a child with recent-onset disease [1]. Further histological confirmation of islet existence in all stages of diabetes came in 1959 through to 1985 [2-6], as well as more recently [7-10]. Despite this evidence, the accepted opinion persisted that the pancreas functionally dies a couple of years after diagnosis for the majority of patients. It has so dominated the diabetes field and clinical practice that there is not a clinician, including myself, who has not explained the disease in this way to families. Clinicians caution that the so-called 'honeymoon' would be over soon and the pancreas would be dead after that time. In fact, one of the most cited papers on the natural history of diabetes by George Eisenbarth contains a figure depicting the rapid postdiagnosis demise of pancreas function measured by C-peptide, the protein co-secreted with insulin [11]. The image is so 
powerful that it is used as a staple in medical schools and is also frequently shown to diabetes researchers.

The consequence of this belief has been that researchers and clinicians have exclusively focused on new-onset diabetic volunteers for interventional immune trials. The purpose is to slow the inevitable death of the few functioning islets rapidly after diagnosis. Over the last 20 years, most, if not all, human immune intervention trials in type 1 diabetes have studied only new-onset diabetes cases (or individuals with impaired glucose tolerance) under the premise that the pancreas only lasted a short while and that was the only time to save the organ.

I did not question the dogma on the human pancreas functional decline until 2008. My laboratory launched an immune intervention trial in diabetic patients with long-standing disease (a mean of 15 years) who had 'no' fasting or stimulated C-peptide as assessed by conventional clinically approved assays [12]. We were motivated to apply an immune intervention in long-term diabetic patients because the immunotherapy (Bacillus Calmette-Guerin, BCG) had been successful in end stages, not just new-onset disease, in an animal model of type 1 diabetes, the NOD mouse [13]. A condition of enrolment in our human clinical trial was no fasting or stimulated C-peptide by traditional assay methods that detect C-peptide to a lower level of about $40 \mathrm{pmol} / \mathrm{l}$. To our astonishment, when all weekly blood sera were analysed by an ultrasensitive C-peptide assay at the end of the double-blind trial, all long-term type 1 diabetic participantsrecipients of immunotherapy as well as placebo volunteers, even before randomisation - had low yet detectable levels of insulin secretion as measured by C-peptide. We were galvanised to conduct a follow-up study of nearly 200 long-term diabetic patients in which we assayed C-peptide using the same ultrasensitive assay, which has a lower detection limit of 1.5-2.5 pmol/l. In this study, C-peptide secretion decayed gradually over the course of 20 years, not the 1-2 year honeymoon time course [14]. Also, patients with hyperglycaemia had higher C-peptide levels than those with normoglycaemia, a finding that indicated appropriate islet beta cell function. Overall, using the ultrasensitive C-peptide assay, $63 \%$ of samples, which were from patients with a mean diabetes duration of 19 years, exhibited detectable levels of C-peptide.

We now have the benefit of a new study by Oram and colleagues in this issue of Diabetologia [15]. This important study investigates $\mathrm{C}$-peptide in long-term diabetes and whether it responds to a formal meal stimulus test. The study measured C-peptide in both serum and urine. It relied on an electrochemiluminescence C-peptide immunoassay with a low detection limit of $3.3 \mathrm{pmol} / \mathrm{l}$. Recruiting 74 participants with a diabetes duration $>5$ years, the new study found detectable levels of C-peptide in $73 \%$ of patients after a mixed-meal tolerance test and in $66 \%$ of patients upon fasting. Low-level C-peptide was functionally responsive, as revealed by $80 \%$ of patients responding to a mixed meal by a rise in $\mathrm{C}$-peptide secretion.

\section{A new outlook}

What to make of this new and important study? It confirms and elegantly expands what turns out to have been a decadeslong track record of scientific scrutiny finding intact islet beta cells with advanced disease. With its demonstration that those remaining pancreatic cells are functional, the study shifts the weight of the evidence in favour of a partially viable human pancreas long after type 1 disease onset and one that is responsive to physiological stimuli. The study should counter the therapeutic nihilism that has left most long-term patients adrift; it is now clear that they, too, might benefit from new immunotherapies and should be included in clinical trials. Still, it must be acknowledged that immunotherapies have a disappointing track record in terms of restoring or preserving islet cell function in individuals with new-onset diabetes.

The study by Oram and colleagues [15] and Wang and colleagues [14] also help to interpret other scientific observations reported more than 15 years ago. The first observation was in identical twins discordant for type 1 diabetes for more than 20 years. When the healthy twin donated half a pancreas to the diabetic twin, the transplant unexpectedly failed within several weeks, rather than years like a new immune response. The diabetic twin mounted a rapid and vicious autoimmune response, decades after the autoimmunity was viewed as gone owing to the concept that the endogenous pancreas had been dead [16]. The other unexplained long-standing observation was that two-thirds of individuals with a diabetes duration of 10 years tested positive for at least one diabetes-associated autoantibody and $42 \%$ of individuals tested positive for two to three autoantibodies [17]. With the benefit of hindsight, these observations - one with T cells and the other with B cellscan be explained by the persistence of low-level islet cell regeneration or long-term islet survival perpetuating active autoimmunity years and years after the onset of disease.

Why were we wrong for so long? One obvious answer is that the histology showing intact islets beta cells was not accompanied by sensitive functional studies. Another is that the traditional C-peptide assays were great for the detection of high C-peptide levels but were too insensitive to measure small amounts of C-peptide. Perhaps a third answer is that we were misled by the NOD mouse, which still seems to have a rapid drop-off of C-peptide soon after disease onset. Here is one example where the human and the animal models of type 1 diabetes may diverge. Luckily for us, humans might have a more indolent course of $\mathrm{T}$ cell attack or may have superior powers of chronic regeneration. To date, brisk islet regeneration has been observed in the NOD mouse in response to therapy [18]; it is not yet known whether this pancreatic recovery response will be the same in humans with targeted disease removal.

There will be some who argue that the residual C-peptide production in long-term diabetes is not clinically meaningful 
in the detectable range ( 1.5 to $40 \mathrm{pmol} / \mathrm{l})$ of the new hypersensitive C-peptide assays. The study by Oram et al starts to refute that assertion [15]. It may turn out that C-peptide levels help us to understand why some patients are prone to complications, including lethal hypoglycaemia, as assays with refined sensitivity are developed and, more importantly, correctly applied. Further data is sure to come to address this important question. C-peptide may turn out to be a diagnostic of insulin production for use in the clinic along with the well-established $\mathrm{HbA}_{1 \mathrm{c}}$. The fact that this new study in Diabetologia also shows that C-peptide can be measured accurately in urine will enable more frequent patient monitoring. The take-home message of the paper by Oram and colleagues is that a large fraction of patients with long-standing diabetes have low-level, but persistent functioning of pancreatic islet cells. This implies that most individuals with long-term type 1 diabetes should perhaps now be given the same opportunity as individuals with new-onset disease to participate in clinical trials on immune intervention therapy seeking to preserve insulin secretion if innovative ideas to halt long-standing autoimmunity, not just acute autoimmunity, can be thoughtfully devised.

Acknowledgements The author thanks M. Davis for her editorial revisions and L. Murphy for her formatting of the manuscript, both of the Massachusetts General Hospital.

Duality of interest The author declares that there is no duality of interest associated with this manuscript.

Contribution statement The author is the sole contributor to this paper.

\section{References}

1. Schmidt MB (1902) Über die Beziehung der Langerhans'schen Inseln des Pankreas zum Diabetes mellitus. Münch med Wochenschr 49:51-54 [article in German]

2. Maclean N, Ogilvie RF (1959) Observations on the pancreatic islet tissue of young diabetic subjects. Diabetes 8:83-91
3. Gepts W (1965) Pathologic anatomy of the pancreas in juvenile diabetes mellitus. Diabetes 14:619-633

4. Doniach I, Morgan AG (1973) Islets of Langerhans in juvenile diabetes mellitus. Clin Endocrinol 2:233-248

5. Junker K, Egeberg J, Kromann H, Nerup J (1977) An autopsy study of the islets of Langerhans in acute-onset juvenile diabetes mellitus. Acta Pathol Microbiol Scand A Pathol 85:699-706

6. Foulis A (1985) Autumn Books: Bernard on le pancreas. BMJ 291: 1182

7. Meier JJ, Bhushan A, Butler AE, Rizza RA, Butler PC (2005) Sustained beta cell apoptosis in patients with long-standing type 1 diabetes: indirect evidence for islet regeneration? Diabetologia 48: 2221-2228

8. Willcox A, Richardson SJ, Bone AJ, Foulis AK, Morgan NG (2009) Analysis of islet inflammation in human type 1 diabetes. Clin Exp Immunol 155:173-181

9. Atkinson MA, Gianani R (2009) The pancreas in human type 1 diabetes: providing new answers to age-old questions. Curr Opin Endocrinol Diabetes Obes 16:279-285

10. Keenan HA, Sun JK, Levine J et al (2010) Residual insulin production and pancreatic $\beta$-cell turnover after 50 years of diabetes: Joslin Medalist Study. Diabetes 59:2846-2853

11. Eisenbarth GS (1986) Type I diabetes mellitus: a chronic autoimmune disease. N Engl J Med 314:1360-1368

12. Faustman DL, Wang L, Okubo Y et al (2012) Proof-of-concept, randomized, controlled clinical trial of Bacillus-Calmette-Guerin for treatment of long-term type 1 diabetes. PLoS One 7:e41756

13. Ryu S, Kodama S, Ryu K, Schoenfeld DA, Faustman DL (2001) Reversal of established autoimmune diabetes by restoration of endogenous beta cell function. J Clin Invest 108:63-72

14. Wang L, Lovejoy NF, Faustman DL (2012) Persistence of prolonged C-peptide production in type 1 diabetes as measured with an ultrasensitive C-peptide assay. Diabetes Care 35:465-470

15. Oram RA, Jones AG, Besser REJ et al (2013) The majority of patients with long-duration type 1 diabetes are insulin microsecretors and have functioning beta cells. Diabetologia. doi:10.1007/s00125013-3067-x

16. Sutherland DE, Sibley R, Xu XZ, Michael A, Srikanta AM, Taub F, Najarian J, Goetz FC (1984) Twin-to-twin pancreas transplantation: reversal and reenactment of the pathogenesis of type I diabetes. Trans Assoc Am Phys 97:80-87

17. Savola K, Sabbah E, Kulmala P, Vähäsalo P, Ilonen J, Knip M (1998) Autoantibodies associated with type I diabetes mellitus persist after diagnosis in children. Diabetologia 41:1293-1297

18. Kodama S, Kuhtreiber W, Fujimura S, Dale EA, Faustman DL (2003) Islet regeneration during the reversal of autoimmune diabetes in NOD mice. Science 302:1223-1227 